\title{
The concept of management of economic security of the railway transport in the context of overcoming the manifestations of a systemic crisis
}

\author{
Volodumur Dykan ${ }^{1}$, Iryna Tokmakova ${ }^{1}$, Volodymyr Pavlichenko ${ }^{2}$, Oleksandr \\ Cherednychenko ${ }^{3}$ and Myroslava Korin ${ }^{1 *}$ \\ ${ }^{1}$ Ukrainian State University of Railway Transport, Department of Economics and Management of \\ Industrial and Commercial Business, Feuerbach sq. 7, 61050 Kharkiv, Ukraine \\ ${ }^{2}$ Kharkov Institute of Finance Kyiv National University of Trade and Economics, Pletnevsky lane 5, \\ 610500 Kharkiv, Ukraine \\ ${ }^{3}$ Yaroslav Mudryi National Law University, Department of Juridical Personnel Training Institute for \\ the Security Service of Ukraine, Pushkinskaya st. 77, 61024 Kharkiv, Ukraine
}

\begin{abstract}
The article analyzes the trends in the functioning of railway transport in Ukraine, which allowed to identify the manifestations of the systemic crisis in the industry. On this basis, the risks and threats to the economic security of rail transport are highlighted. The concept of management of economic safety of railway transport is formed. The object and subject of management of economic safety of railway transport, principles and purpose are defined. The tools of management of economic safety of railway transport in the following directions are revealed: formation of institutional and organizational basis of development of railway transport; providing innovative transformations to improve technological capabilities and raise the level of security; ensure social development and competencies of staff to increase loyalty; create communications to maintain effective communication of railway transport and development of partnerships.
\end{abstract}

\section{Introduction}

Today, rail transport is going through perhaps the most difficult period in the history of its own operation. Long-term processes of reforming the industry in conditions of aggravation of macroeconomic instability in the country led to the immersion of Ukrzaliznytsia JSC in the state of economic crisis and deterioration of their economic security. For the most part, the trends in the functioning of rail transport, reflecting the accumulation of problems over many years, are extremely threatening to maintain the sustainable development of the industry. The decline in transportation volumes, depreciation of fixed assets, staff outflow and loss of investment, the decline in profitability

* Corresponding author: miraslava87@ukr.net 
and solvency, the growth of dependence on foreign currency borrowings became the basis for the loss of stability of the industry to threats, opportunities for development and maintaining the image among key stakeholders.

\section{Analysis of research and publications on the management of economic security of railway transport}

The problem of economic security management of enterprises, including rail transport, is carefully studied by specialists and scientists of foreign and Ukrainian scientific schools. The theoretical basis of economic security management and its tools are thoroughly reflected in the works of such scientists as L. Abalkin, O. Arefieva, E. Vaughan, L. Donets, P. Drucker, Yu. Zhalilo, O. Lyashenko, C. Peterson, M. E. F. Seligman, N. Reverchuk [1-10]. Scientific search for tools to support the economic security of rail transport devoted their research V. Dukan, G. Eitutis, I. Volovelsky, V. Ovchynnikova, I. Nazarenko, I. Tokmakova and others [11-17]. In general, assessing the significant contribution of the developments and proposals of these scientists to the development of the theory and methodology of economic security of railway transport in the context of aggravation of manifestations of the systemic crisis in the railway industry, there is a need to develop the concept of economic security management.

\section{Study of manifestations of the systemic crisis in the railway transport of Ukraine}

Trends in the functioning of rail transport in recent years indicate the continued instability and unpredictability of the economic situation in the industry. Despite some progress in reforms, the restoration of positive dynamics of results of operations in General, rail transport has long stretched production capacity. Destabilizing impact on the economic situation of JSC «Ukrzaliznytsia» have a variety of risks and threats that exist in the environment of its functioning.

Rail transport is made economically vulnerable by industry-specific internal threats and risks to its operation (Fig. 1). The most threatening impact was the fall in the volume of work of Ukrzaliznytsia JSC, which created the risk of loss of income and investment and provoked the deterioration of solvency and credit ratings of railway transport. Turning to the data of statistics, it is worth noting that although the level of profitability of railways from freight traffic is significantly increasing in dynamics (growth in five years amounted to UAH 28.2 million), but the rate of increase due to the rise in tariffs for transportation. Thus, only for the period 2014-2017, the average annual tariff for transportation of 1 ton of goods in the industry increased by $72.27 \mathrm{UAH} / \mathrm{t}$ or $94.7 \%$ [18]. In fact, the support of financial and economic stability in railway transport is not due to the growth of the volume of work of the industry, but to the increase in the cost of services for consumers.

The increase in the profitability of freight transportation, provided by the increase in tariffs for services of ukrainian railways, contributed to the revival of investment activity of railway transport in the field of updating the technological base. However, the problem is that the increase in the size of capital investments of JSC «Ukrzaliznytsia» in the renewal of fixed assets was also due to the increase in the size of foreign currency borrowings of railway transport, which in the conditions of increasing negative dynamics of volume indicators of the industry created a threat of loss of solvency and the situation of technical default on rail transport. Due to the accumulation of foreign currency borrowings (in 2017, the foreign currency component of the loan portfolio amounted to $98 \%$, while in $2014-$ $84 \%$, in $2015-83 \%$ ) [19-20] and the financial insolvency of railways to pay for their loan 
obligations, there was a deterioration in the investment and credit ratings of rail transport and provoked a threat of loss of confidence on the part of key investors.

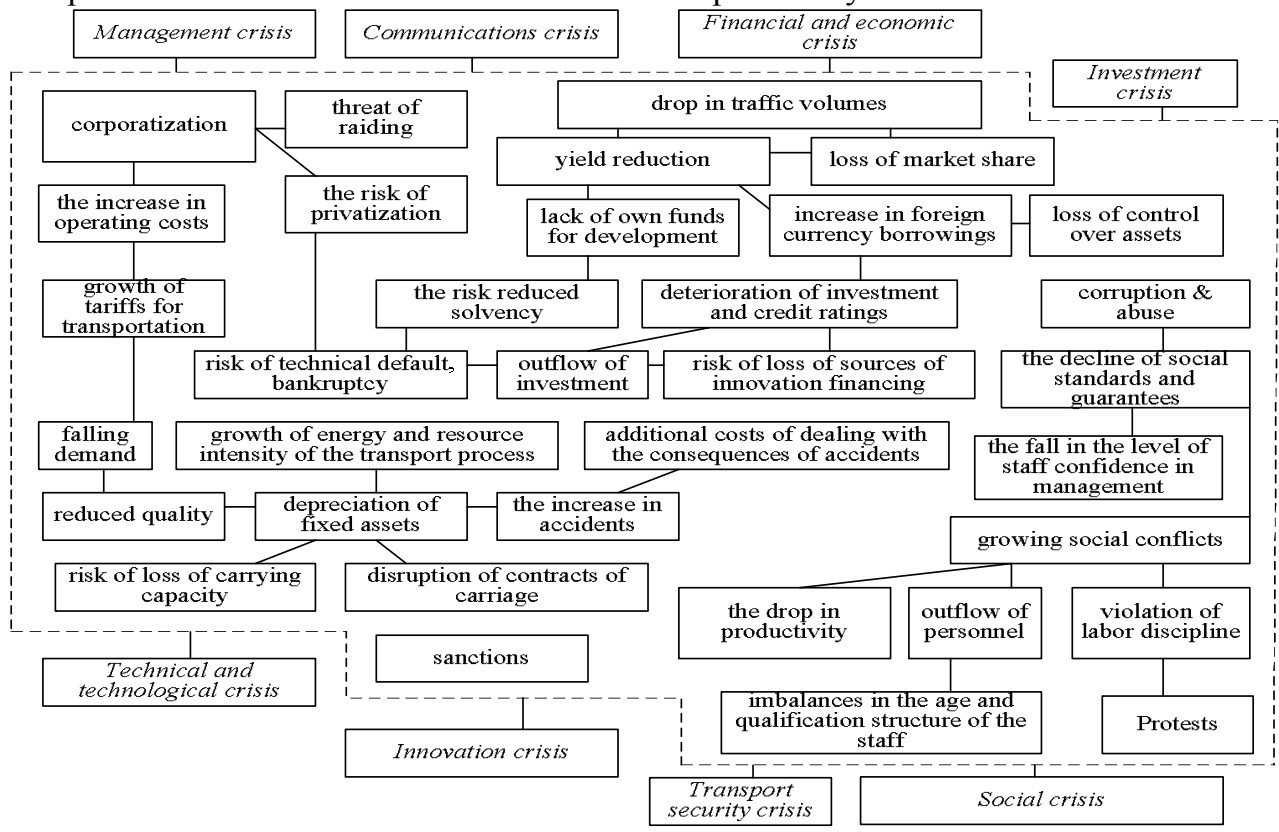

Fig. 1. Risks and threats to the economic security of railway transport

Increases and the threat of losing a share of the transport market by reducing demand for services of JSC «Ukrzaliznytsya» in the sphere of cargo and passenger traffic. The reorientation of freight and passenger traffic to road transport is provoked by the low quality of railway transport services, which in the conditions of raising tariffs does not meet either the requirements of consumers or service standards. On the one hand, the low quality of services of JSC «Ukrzaliznytsia» is the result of a deep technical and technological crisis that has taken place in the industry for decades. As evidenced by the official data of JSC «Ukrzaliznytsia» to date, the technical and technological capabilities of the company are on a critical verge, and their condition and quantity is not able to meet the existing demand in the country for transportation. First and foremost there is a huge shortage of locomotives (in use is 1857 units, representing 51.4 per cent), trucks (inventory Park 64 thousand units) and passenger cars (inventory of Park - 4220 units, the average age is $31.6 \mathrm{~g}$ ), and railcar rolling stock in particular, electricity (the wear rate of $87.5 \%$ ) and diesel trains (the wear rate of 97,2\%) [19-21]. Vray is critical and the situation of railway infrastructure, most of which have long been operated with overdue repairs. Even despite the revival of the investment policy of JSC «Ukrzaliznytsia» in the direction of renewal and acquisition of rolling stock, in General, the industry has a situation of further accumulation of technically worn-out fixed assets. Plans in the field of capital investments of JSC «Ukrzaliznytsia» for the coming years are expected to purchase 110 freight and 90 passenger electric locomotives, 70 freight locomotives and more than 40 double-feed electric locomotives [21], and a significant (about 650 units) renewal of the wagon fleet is announced.

This state of Affairs with the main funds of railway transport provokes the growth of unreliability and distrust of JSC «Ukrzaliznytsia» from the leading partners in particular, manufacturers of industrial and agricultural products, forcing the latter to form their own car fleet to prevent violations in the supply. This led to a situation in which the inventory fleet of ukrainian railways is less than 1 thousand units of private freight cars (65 thousand units) [21]. 
Along with this, the situation with the lack of rolling stock provokes the industry to implement economically harmful measures both for railway transport and the economy as a whole. So, implementing the model of corporatization, JSC «Ukrzaliznytsia» is considering the possibility of the admission of private locomotives, leaving behind the industry, the function of the operator of the railway infrastructure. This, in turn, creates the risk of insolvency and bankruptcy of railway transport, because the appearance of private operators in the transport market means for the industry, further tightening of reforms and even more growth of operating costs of JSC «Ukrzaliznytsia», the concentration of lowincome areas of activity.

The processes of social transformations in the industry also pose a threat to the effective functioning of ukrainian railways. On the one hand, already today, through the deterioration of the level of social security of workers in the industry, there is an increase in the manifestations of the social crisis. Social tension in the labor collectives of JSC «Ukrzaliznytsia», which was the result of inaction and systematic violation of the legislation and the requirements of workers, led to the most large-scale for the entire period of existence of the ukrainian railways outflow of personnel. Over the period 2014-2017, the average number of employees in core activities decreased from 293.7 thousand to 219.1 thousand persons, that is, by 74.6 thousand or $25.4 \%$ [22]. The reduction in the number of employees provoked a drop in the level of labor productivity in the industry and led to an increase in qualification and age disparities in the structure of personnel. The reduction of social standards and guarantees for the majority of employees against the background of a constant increase in the salaries of management staff has provoked an increase in dissatisfaction and conflict in the staff of railways, causing the risk of loss of qualified human resources and the aggravation of the crisis of trust of railway transport management.

So, we can say with confidence that despite the positive dynamics in the field of reforms and implementation of the corporate management model, in General, the situation in railway transport is of a crisis nature and leads not only to the loss of competitive positions of ukrainian railways in the transport market, but also predetermines a sharp deterioration in the level of their economic security, making it impossible to implement strategic initiatives to support the economic development of railway transport. In the context of the reform and variability of the external environment of railway transport, the strategic directions of increasing the level of economic security should be focused on neutralizing the impact of existing threats and increasing the adaptability of the industry to changes in the transport market.

\section{Determination of directions and development of the concept of management of economic safety of railway transport in the conditions of system crisis}

The level of economic security of railway transport as well as any enterprise today is closely connected with such trends of economic development as intellectualization of work and socialization of personnel, Informatization of business processes and systems, their innovative transformation and integration. The ability to respond effectively to the challenges and threats to its economic security depends on the level of adaptation of the enterprise to such global development trends. In accordance with this, and taking into account the manifestations of the systemic crisis in railway transport, the management of economic security of the industry should provide for its adaptation to changing external conditions and be accompanied by the implementation of effective measures aimed at overcoming negative trends in intra-industry development. Based on the theoretical basis of the studied problems of management of economic security of railway transport will be considered in terms of a combination of management tools of institutional and 
organizational changes, innovation,investment and personnel management, as well as the introduction of tools of integrated marketing communications to maintain effective relations and development of partnership with key stakeholders and leveling on this basis of threats of systemic crisis (Fig. 2).
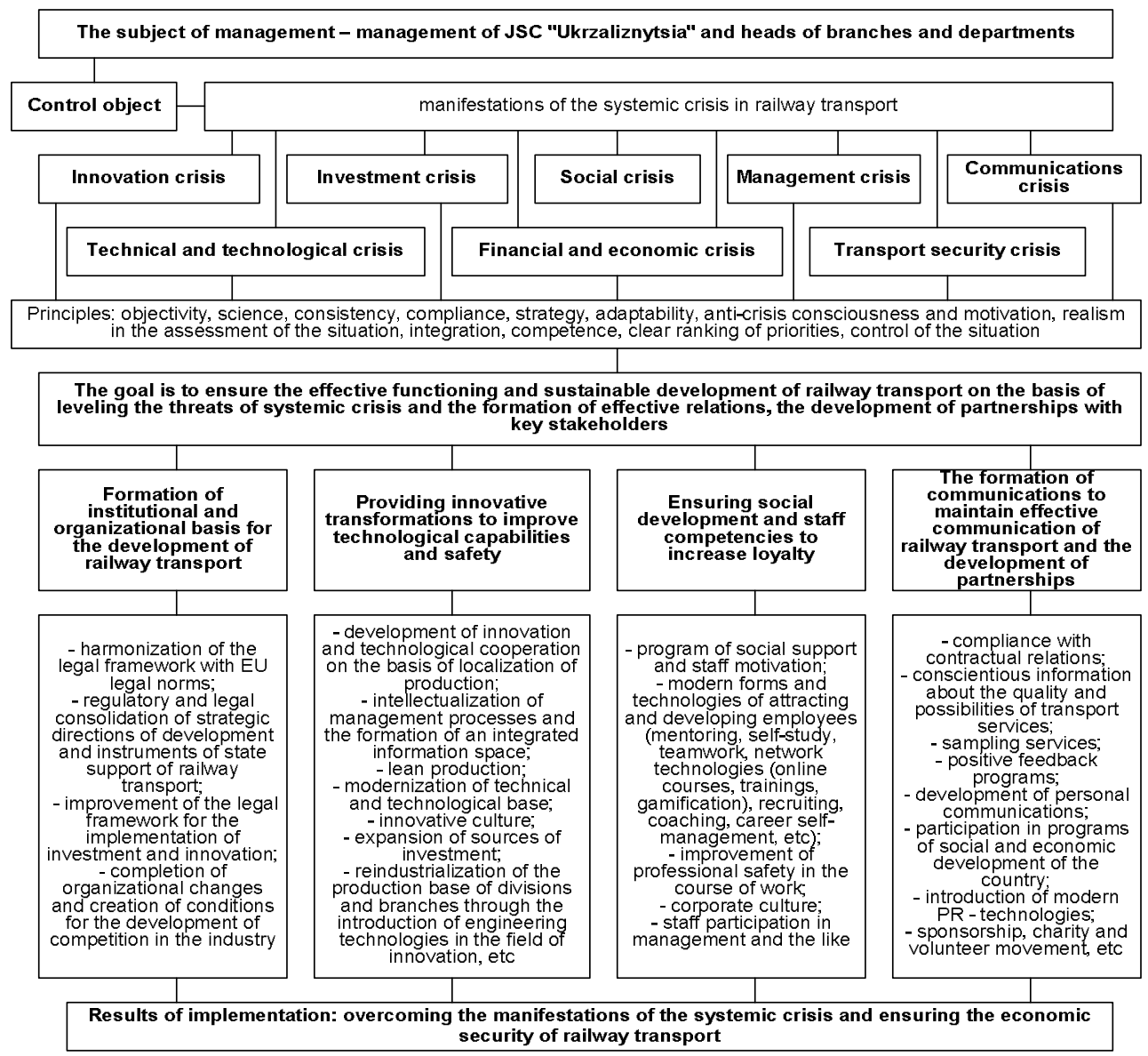

Fig. 2. The concept of management of economic safety of railway transport in the conditions of system crisis

Accordingly, it should be based on tools in the following areas: the formation of institutional and organizational basis for the development of rail transport; providing innovative transformations to improve technological capabilities and improve safety; ensuring social development and staff competencies to increase loyalty; the formation of communications to maintain effective rail transport links and the development of partnership. Their implementation will allow us not only to overcome the symptoms of a systemic crisis in railway transport, but also significantly increase the level of its economic security, creating the conditions to support the financial, economic, social, environmental efficiency of Ukrzaliznytsya JSC, the strengthening of the business position and image of the industry in the transport market.

\section{Conclusion}


The modern stage of development of railway transport is characterized by the aggravation of crisis processes in the industry. Technological degradation as a result of low level of innovative activity, loss of investments and qualified personnel in the conditions of deterioration of volume indicators of work of branch led to deterioration of level of economic safety of railway transport and loss of competitive positions in the market of transportations. The concept of management of economic safety of railway transport establishes the subject and object, principles and objectives, and also reveals the tools of management of economic safety of railway transport in three directions, the implementation of which will create a basis for leveling the existing risks and threats in the industry, ensuring its sustainable development.

\section{References}

1. L.I. Abalkin, Voprosy ekonomiki, 12, 4-13 (1994)

2. O.V. Arefyeva, T.B. Kuzenko, Planuvannya ekonomichnoyi bezpeky pidpryyemstv, Kyiv, 172 (2004)

3. E.J. Vaughan, Fundamentals of Risk and Insurance, New York, 723 (1986)

4. L.I. Donets, N.V. Vashchenko, Ekonomichna bezpeka pidpryyemstva, Kyyiv, 240 (2008)

5. P.F. Drucker, Management: Tasks, Responsibilities, Practicies, New York, 840 (1974)

6. YA.A. Zhalilo, Stratehichna panorama, 3, 97-104 (2004)

7. O.M. Lyashenko, Kontseptualizatsiya upravlinnya ekonomichnoyu bezpekoyu pidpryyemstva, Luhansk, 400 (2011)

8. C. Peterson, M.E.F. Seligman, Journal Psychological Review, 91, 347-374 (1984)

9. N. Y. Reverchuk, Upravlinnya ekonomichnoyu bezpekoyu pidpryyemnytskykh struktur, Lviv, 195 (2004).

10. V.L. Dykan, I.V. Volovelskaya, Visnyk ONU imeni I.I. Mechnykova, 1, 82-85 (2016)

12. H.D. Eytutis, D.V. Popova, Visnyk ekonomiky transportu i promyslovosti, 62, 29-36 (2018)

15. V.O. Ovchynnikova, Stratehichne upravlinnya rozvytkom zaliznychnoho transportu Ukrayiny, Kharkiv, 427 (2017)

16. I.L. Nazarenko, S.V. Chernenko, Visnyk ekonomiky transportu i promyslovosti, 62, 89-96 (2018)

17. I.V. Tokmakova, K.V. Dudka, Visnyk ekonomiky transportu i promyslovosti, 48, 194-197 (2014)

18. Zmina taryfiv na perevezennya vantazhiv zaliznychnym transportom $u$ mezhakh Ukrayiny na $2017 \mathrm{rik}$. https://publications.chamber.ua/2017/.../Session_2_Tarifs.pdf ahhh!. Accessed 28 Apr 2019

19. Intehrovanyy zvit 2017: dlya investoriv: ofitsiynyy sayt AT «Ukrzaliznytsya». https://uz.gov.ua/about/investors/issuer/. Accessed 08 May 2019

20. Intehrovanyy zvit 2018: dlya investoriv: ofitsiynyy sayt AT «Ukrzaliznytsya». https://uz.gov.ua/about/investors/issuer/. Accessed 08 May 2019

21. Forum Rail Expo 2018 buv maydanchykom dlya obhovorennya onovlennya lokomotyvnoho parku. https:/info.uz.ua/articles/forum-rail-expo-2018-stavmaydanchikom-dlya-obgovorennya-onovlennya-vitchiznyanogo-lokomotivnogo-parku ahhh!. Accessed 20 Apr 2019

22. Dovidnyk osnovnykh pokaznykiv roboty rehionalnykh filiy PAT «Ukrayinska zaliznytsya» (2002-2017 roky): Publichne aktsionerne tovarystvo «Ukrayinska zaliznytsya». Upravlinnya statystyky, Kyyiv, 36 (2018) 